\title{
Broadband Infrastructure and Economic Growth
}

\author{
Nina Czernich \\ Oliver Falck \\ Tobias Kretschmer \\ Ludger Woessmann
}

\author{
CESIFO WORKING PAPER NO. 2861 \\ CATEGORY 6: FisCAL POLICY, MACROECONOMICS AND GROWTH \\ DECEMBER 2009
}
An electronic version of the paper may be downloaded
- from the SSRN website: Www.SSRN.com
- from the RePEc website: Www.RePEc.org
- from the CESifo website: www.CESifo-group.org/wp




\title{
Broadband Infrastructure and Economic Growth
}

\begin{abstract}
We estimate the effect of broadband infrastructure, which enables high-speed internet, on economic growth in the panel of OECD countries in 1996-2007. Our instrumental-variable model derives its non-linear first stage from a logistic diffusion model where pre-existing voice-telephony and cable-TV networks predict maximum broadband penetration. We find that a 10 percentage-point increase in broadband penetration raises annual per-capita growth by $0.9-1.5$ percentage points. Results are robust to country and year fixed effects and controlling for linear second-stage effects of our instruments. We verify that our instruments predict broadband penetration but not diffusion of contemporaneous technologies like mobile telephony and computers.
\end{abstract}

JEL Code: O47, L96, K23.

Keywords: broadband, high-speed internet, technology diffusion, economic growth.

Nina Czernich

Ifo Institute for Economic Research at the University of Munich

Poschingerstrasse 5

Germany - 81679 Munich

czernich@ifo.de

Tobias Kretschmer

Institute for Communication Economics

University of Munich

Schackstrasse 4

Germany - 80539 Munich

t.kretschmer@Imu.de
Oliver Falck

Ifo Institute for Economic Research at the University of Munich

Poschingerstrasse 5

Germany-81679 Munich

falck@ifo.de

Ludger Woessmann

Ifo Institute for Economic Research at the University of Munich

Poschingerstrasse 5

Germany - 81679 Munich

woessmann@ifo.de

1 December 2009

The research underlying this paper has been partially supported by Deutsche Telekom AG. The views expressed are those of the authors and do not necessarily reflect the views of Deutsche Telekom AG. Comments by Matthias Doepke, Mario Larch, Monika Piazzesi, Martin Schneider, and Michèle Tertilt are gratefully acknowledged. 


\section{Introduction}

High-speed internet access via broadband infrastructure has developed rapidly worldwide since the late 1990s. Broadband infrastructure allows the generation and distribution of decentralized information and ideas in markets increasingly relying on information as an input. In light of modern theories of endogenous growth (e.g., Romer 1990), this should accelerate economic growth by facilitating the development and adoption of innovation processes. In this way, broadband infrastructure may differ not only from other types of public infrastructure such as roads and bridges, but also from more traditional telecommunications infrastructure. While the latter's impact on economic growth has been analyzed before (Röller and Waverman 2001), the new growth theories suggest that the growth effects of modern communication networks that have emerged since may have a different quality. Voice-telephony infrastructure has a coordination function and reduces transaction costs for existing businesses. On top of that, high-speed internet via broadband infrastructure may accelerate the distribution of ideas and information and foster competition for and development of new products, processes, and business models, thereby further facilitating macroeconomic growth.

In this paper, we test the effect of broadband infrastructure on economic growth using an annual panel of 25 OECD countries in 1996-2007 (broadband introduction started in 1997 in the first country). Considering that broadband penetration may be endogenous to the growth process, our empirical identification builds on the idea that broadband roll-out tends to rely on traditional voice-telephony and cable-TV networks. Therefore, we specify a technology diffusion model in which variations in the ceiling of the broadband diffusion curve across countries are determined by the extent of the pre-existing traditional networks. Using only the part of the variation in broadband penetration that can be predicted by this diffusion model, we find a significant positive effect of broadband introduction and penetration on economic growth. Our instrumental-variable results suggest that a 10 percentage-point increase in the broadband penetration rate results in a 0.9-1.5 percentage-point increase in annual per-capita growth.

Broadband internet and the underlying infrastructure fulfill many characteristics of a general purpose technology (GPT) that fundamentally changes how and where economic activity is organized (Harris 1998; Helpman and Trajtenberg 1998). With its potential to facilitate decentralized information processing and to support new working modes (Bloom and Van 
Reenen 2007; Bloom, Kretschmer, and Van Reenen 2009), broadband may constitute a special technology with an impact on growth distinct from other technologies emerging around the same time. High-speed internet via broadband infrastructure facilitates the spatial distribution of large batches of information that previously had to be collocated, which in turn allows for new business models and collaboration of firms producing specialized inputs. This can lead to lower entry barriers and higher market transparency, thereby increasing both labor productivity and market competition and ultimately economic growth. Thus, some casual observers have linked the fact that OECD countries have grown substantially in the late 1990s and early 2000s to the contemporaneous emergence of broadband (OECD 2000).

Indeed, we show that there is a significant positive association between broadband deployment and economic growth in the panel of OECD countries since the mid-1990s. However, this simple association may be driven by reverse causality and omitted variables. First, individuals in high-income countries may also have a high ability to pay for broadband services, resulting in more rapid broadband penetration. Second, state intervention in telecommunications might depend on the level of economic development in a country, thus confounding the effect of regulation and sectoral policies with the effect of broadband diffusion. Third, given the rapid technological change in the last decades, broadband diffusion took place at the same time as the diffusion of other technologies like mobile telephony and computers (Comin, Hobijn, and Rovito 2008), making it difficult to isolate the specific effect of broadband.

To address these problems, we develop an instrumental-variable (IV) approach based on the fact that broadband deployment takes place alongside existing infrastructure elements, which creates path dependencies given the pre-existing heterogeneity in infrastructure across countries. Thus, our first-stage model is based on a diffusion model of broadband technology in which the extent of pre-existing fixed-line telephony and cable-TV networks determines the maximum reach of the broadband network in each country. These existing networks only affect the supply side of broadband diffusion and therefore rule out demand-side effects due to differences in wealth and growth and policy-induced effects. Drawing on the large literature on technology diffusion models (e.g., Geroski 2000), we specify a logistic diffusion curve where maximum broadband penetration is limited by the extent of the traditional networks. Combining these pre-existing instruments with the logistic shape of the diffusion curve allows us to predict broadband penetration in a country over time. The predicted values 
of the broadband penetration rate from this non-linear first stage help us identify the effect of broadband on economic growth in the second stage.

We specify two types of second-stage models. In the first, GDP per capita is modeled as a function of a dummy for broadband introduction in a difference-in-differences specification. Our IV results show that GDP per capita is about 2.7 to 3.9 percent higher on average after than before broadband introduction, controlling for country and year fixed effects. The second type of the second-stage model specifies a classical cross-country growth model where the broadband penetration rate is added as a determinant of the growth rate of GDP per capita. We find that an increase in the broadband penetration rate by 10 percentage points increases annual per-capita GDP growth by 0.9 to 1.5 percentage points over our sample period.

Our results are robust to the inclusion of country and time fixed effects as well as a number of control variables and to the specific set of countries in our sample. Given that our first-stage model is non-linear, we can include our instruments linearly in the second-stage model, which again does not affect our results. Further, we show that our instruments indeed determine the ceiling for broadband but not the diffusion of other potentially growth-enhancing technologies like mobile telephony and computers diffusing at about the same time. These results confirm the validity of our instruments and underline the causal character of the growth effect of broadband infrastructure.

The remainder of the paper is organized as follows. Section 2 briefly summarizes prior work on broadband and economic growth. Section 3 introduces a simple growth regression framework and our database and presents results on the association between broadband penetration and economic growth. Section 4 develops our IV approach, presents results on the causal effect of broadband penetration on economic growth, and tests for instrument validity and robustness. Section 5 concludes.

\section{Literature on Broadband and Economic Growth}

Theories of endogenous growth model the generation and distribution of ideas and information as the key driver of economic growth (Lucas 1988; Romer 1990; Aghion and Howitt 1998). Against this background, high-speed internet via broadband infrastructure may affect the innovative capacities of the economy through development of new products, processes, and business models to promote growth. Moreover, cheaper information dissemination can facilitate the adoption of new technologies devised by others, which again 
promotes economic growth (Nelson and Phelps 1966; Benhabib and Spiegel 2005). This also suggests that spillovers of codified knowledge across firms and regions may constitute another channel by which information technology in general and broadband deployment in particular affect economic growth. ${ }^{1}$

Broadband internet enables the exchange of data across multiple locations and aids decentralized information processing (see Hayek 1945 for a conceptualization of the importance of decentralized information processing). Every actor in an economic system uses existing information as an input to generate new informational output. During information processing, the actor can enrich and evaluate the initial information due to experience and a different perspective and understanding, which eventually leads to a multiplication of information for the benefit of all actors. Beyond the reduction of costs of existing business processes arising from the emergence of telecommunications infrastructure for voice telephony, high-speed internet enables the emergence of new business and firm-cooperation models that rely on the spatial exchange of large batches of information, which fosters competition and innovation processes. On the demand side, broadband internet may increase market transparency and thus additionally intensify competition.

Broadband infrastructure, when combined with information technologies, can also affect firm productivity and economic growth in additional ways. The development of information technologies fundamentally changed and improved the processing of information, resulting in significant productivity growth of IT-using firms (Stiroh 2002; Jorgensen, Ho, and Stiroh 2008). The recent literature on productivity effects of information technologies (IT) also recognizes that these effects depend on how information technologies are used and on the presence of complementary inputs such as skilled labor (Autor, Levy, and Murnane 2003) or organizational structure and practices (Bresnahan, Brynjolfsson, and Hitt 2002; Bloom and Van Reenen 2007; Bloom, Kretschmer, and Van Reenen 2009). The isolated analysis of a firm's IT investment on productivity might also neglect positive interactive effects of a firm's IT investments with broadband internet connecting actors across locations. For example, eprocurement, e-billing, online recruitment, and customer services are activities that are only possible through both firm-level IT investment and economy-level broadband infrastructure.

\footnotetext{
${ }^{1}$ By contrast, Audretsch and Feldman (1996) show that spillovers of tacit knowledge are regionally bound as they typically require face-to-face contact.
} 
Although broadband infrastructure as a general purpose technology may have a more farreaching effect on economic growth than other, possibly similar technologies, ${ }^{2}$ previous studies on earlier infrastructure technologies serve as a useful reference point both in methodological terms as well as in assessing the impact of broadband on economic growth. The effects of public infrastructure on growth found in the pioneering work by Aschauer (1989) have been criticized to be upward biased due to common time trends, reverse causality, omitted variables, and simultaneity. Subsequent analyses find effects of public infrastructure investment on growth that range from zero to effects that are comparable in size to the effects found by Aschauer (for overviews, see Munnell 1992 and Gramlich 1994). Furthermore, Fernald (1999) shows that investment in (road) infrastructure can only explain one-off, unrepeatable shifts in productivity but not permanent shifts in productivity growth.

Closest to our study, Röller and Waverman (2001) analyze how voice telecommunications infrastructure affects economic growth across 21 OECD countries in the 1970s and 1980s. They use a simultaneous equation model to integrate demand and supply in the telecommunications sector into the aggregate economy. A country's surface area and its government deficit identify the supply side of the model, as the surface area directly affects the size of the telecommunications network to be built and the government deficit determined governments' financial ability to invest in telecommunications infrastructure at a time when state monopolies dominated in the telecommunications sector in most countries. Röller and Waverman (2001) find that about one third of growth in OECD countries over the period 1971-1990 can be attributed directly or indirectly to telecommunications. While their estimates are a prime example of addressing causality issues in macroeconomic growth analyses, their period of observation could not yet cover the diffusion of broadband technology, which we study in our paper. As argued above, broadband infrastructure may affect economic growth in different ways from traditional telecommunications infrastructure.

The association between broadband infrastructure and economic development has also been examined in two policy reports, Crandall, Lehr, and Litan (2007) and Gillett, Lehr, Osorio, and Sirbu (2006). Both reports exploit differences in broadband development across U.S. states and find positive associations between broadband penetration and different economic outcome variables such as employment, wages, and housing prices. However, these results

\footnotetext{
${ }^{2}$ Crafts (2004) shows that the contribution of steam power as an example of GPT to productivity growth has been considerable and probably exceeds the productivity and growth effects of public infrastructure investment (Gramlich 1994).
} 
cannot be interpreted as causal effects as both studies lack an empirical strategy to identify the role of broadband causally.

\section{Model Framework, Data, and Descriptive Evidence}

\subsection{A Simple Growth Regression Framework}

We start from a simple macroeconomic production function with constant returns to scale and the three inputs physical capital, human capital, and labor. Following Mankiw, Romer, and Weil (1992), the steady state is given by:

$$
\log y_{i t}=\log A_{i}+\beta_{1} \log s_{i t}+\beta_{2} \log h_{i t}+\beta_{3} n_{i t}
$$

Here, $y_{i t}$ is GDP per capita in country $i$ at time $t, s_{i t}$ is the propensity to accumulate physical capital, $h_{i t}$ is average human capital accumulation of the workforce, and $n_{i t}$ is the growth rate of the workforce. Finally, $A_{i}$ is the state of the technology in country $i$. In this framework, the empirical observation of continuous growth in per-capita GDP can be expressed by a technological state that persistently increases over time and thus drives economic growth. Assuming that the technological state evolves along an exponential growth path over time, it can be written as:

$$
A_{i t}=A_{0} e^{\lambda_{i} t}
$$

where $\lambda_{\mathrm{i}}$ is the growth parameter of technological progress for country $i$.

Assuming that the distribution of ideas and information via broadband internet increases the development of and competition for new products and processes and facilitates the adoption of new technologies devised by others, we expect broadband infrastructure to affect the growth parameter $\lambda_{\mathrm{i}}$. To determine the effect of the introduction of broadband on economic growth, we start with the following simple specification:

$$
\lambda_{i} t=\alpha_{t}+\alpha_{1} D_{i t}
$$

Here, $\alpha_{t}$ are year dummies and $D_{i t}$ is a binary variable equal to one after country $i$ has introduced broadband. This yields a difference-in-differences specification of equation (1):

$$
\log y_{i t}=\alpha_{i}+\alpha_{t}+\alpha_{1} D_{i t}+\beta_{1} \log s_{i t}+\beta_{2} \log h_{i t}+\beta_{3} n_{i t}+\varepsilon_{i t}
$$


Thus, $\alpha_{1}$ gives the effect of the introduction of broadband introduction on GDP per capita, $\alpha_{i}$ capture country-specific effects, and $\varepsilon_{i t}$ is an error term.

The preceding specification assumes that there is a permanent shift in GDP per capita once broadband has been introduced. While this may be true if most benefits from broadband originate from availability and from early adopters, broadband penetration in the entire economy may also positively affect economic growth by continuously spurring innovation processes. To model the effect of broadband diffusion on economic growth, we write

$$
\lambda_{i}=\alpha+\alpha_{1} B_{i}
$$

Here $B_{i}$ is the broadband penetration rate, i.e., the share of the population that has subscribed to broadband in country $i$. Taking first differences, this results in a modified equation (1) in which we additionally control for initial GDP per capita $y_{i 0}$, i.e., one year before the first appearance of broadband (Barro 1991):

$$
\Delta \log y_{i t}=\alpha+\alpha_{1} B_{i t}+\beta_{1} \Delta \log s_{i t}+\beta_{2} \Delta \log h_{i t}+\beta_{3} \Delta n_{i t}+\beta_{4} \log y_{i 0}+\beta_{5} T_{i t}^{B}+\varepsilon_{i t}
$$

We are primarily interested in the effects of persistent differences in broadband penetration rates among countries. We therefore control for the catching-up in broadband diffusion by including the years since broadband introduction in a country, $T_{i t}^{B}$. This ensures that we only compare rates of broadband penetration at the same point in the diffusion process, which may differ across countries.

\subsection{Data for OECD Countries}

Broadband penetration is measured as the number of broadband subscribers per 100 inhabitants, provided by the OECD Broadband Portal. A broadband line is defined as a line (DSL, cable, fiber, or other) that offers download speeds of at least $256 \mathrm{kbit} / \mathrm{s}$. The first country in our sample (Canada) started rolling out broadband in 1997. To start our analyses in the year before any broadband introduction, our first observation year is 1996 .

All data on economic performance are taken from the OECD Economic Outlook and are available until 2007. Real GDP is expressed in 2000 Purchasing Power Parity (PPP) and normalized by the working-age population, defined as the population aged 15-64 years, to control for demographic differences among countries. The propensity to accumulate physical capital is proxied by the ratio of real private non-residential fixed capital formation to real 
private GDP. Human capital accumulation of the workforce is proxied by the average number of years of schooling of the population aged 15-64 (from OECD Education at a Glance).

Complete data are available for a panel of 20 OECD countries on an annual basis in 19962007 (see Table 1 for the list of countries). In models that do not control for investment and education, we can add five more countries with missing data on these control variables (the Czech Republic, Italy, Portugal, South Korea, and Spain). ${ }^{3}$ Table 1 provides descriptive statistics for the countries in our sample.

In addition to the variables described above, Table 1 also reports the year of broadband introduction and the broadband penetration rate in 2008. Broadband first emerged in most countries in the years 1999 and 2000. There are some early adopters - Canada (1997) and the United States (1998) - and some late adopters - Greece (2003), Hungary (2001), and Ireland (2002). In 2008, the three leading countries in terms of broadband subscribers per 100 inhabitants were Denmark (37.2\%), the Netherlands (35.8\%), and Norway (34.5\%). Greece (13.5\%), Portugal (16.0\%), and Hungary (16.8\%) have the lowest penetration in our sample.

\subsection{The Association between Broadband and Economic Growth}

Table 2 reports estimation results of equation (4) that models the effect of broadband introduction on GDP per capita in a difference-in-differences framework that contains fixed effects for each country and year. Model 1 refers to our sample of 20 OECD countries with complete data. Model 2 provides results for the same 20-country sample, but without controls for physical and human capital accumulation and working-age population growth. Changes in physical and human capital accumulation might be the result of innovation, e.g., labor saving technological progress leading to capital deepening and skill-biased technological change (Caroli and Van Reenen 2002). These innovations might in turn be the result of the introduction of broadband. Thus, including the above-mentioned controls suggests that Model 1 estimates a lower bound of the growth-enhancing effect of broadband. Model 3 replicates Model 2 with the full sample of 25 countries.

\footnotetext{
${ }^{3}$ Among the OECD countries, this excludes only Luxembourg (for reasons of size) and Mexico, Poland, the Slovak Republic, and Turkey, which do not have the required control variables and have GDP per capita and broadband penetration rates substantially below all other OECD countries.
} 
Table 1: Descriptive Statistics

\begin{tabular}{|c|c|c|c|c|c|c|c|c|c|}
\hline & $\begin{array}{c}\text { GDP per } \\
\text { capita (PPP) }\end{array}$ & $\begin{array}{c}\text { Growth of } \\
\text { GDP per capita }\end{array}$ & $\begin{array}{c}\text { Capital } \\
\text { formation/GDP }\end{array}$ & $\begin{array}{l}\text { Years of } \\
\text { education }\end{array}$ & $\begin{array}{c}\text { Growth of } \\
\text { working-age } \\
\text { population }\end{array}$ & $\begin{array}{c}\text { First } \\
\text { emergence of } \\
\text { broadband }\end{array}$ & $\begin{array}{l}\text { Broadband } \\
\text { penetration } \\
\text { rate } 2008\end{array}$ & $\begin{array}{l}\text { Voice-telephony } \\
\text { penetration rate } \\
1996\end{array}$ & $\begin{array}{l}\text { Cable-TV } \\
\text { penetration } \\
\text { rate } 1996\end{array}$ \\
\hline Australia & 40.74 (3.12) & $0.02 \quad(0.01)$ & $0.14 \quad(0.02)$ & $6.46 \quad(0.34)$ & $0.013(0.001)$ & 1999 & 25.37 & 50.08 & 1.73 \\
\hline Austria & 43.18 (2.92) & $0.02 \quad(0.01)$ & 0.16 (0.01) & $6.00(0.21)$ & $0.004 \quad(0.002)$ & 1999 & 21.64 & 48.41 & 10.30 \\
\hline Belgium & 42.14 (2.79) & $0.02 \quad(0.01)$ & $0.13 \quad(0.01)$ & $6.69(0.29)$ & $0.004 \quad(0.003)$ & 1999 & 28.09 & 45.52 & 36.01 \\
\hline Canada & $42.46 \quad(3.13)$ & $0.02 \quad(0.01)$ & 0.12 (0.01) & $6.48 \quad(0.08)$ & $0.012(0.001)$ & 1997 & 29.02 & 60.70 & 26.57 \\
\hline Czech Republic & $23.09(2.66)$ & $0.03 \quad(0.02)$ & - & $5.31(0.60)$ & $0.004(0.001)$ & 2000 & 17.18 & 27.31 & 6.04 \\
\hline Denmark & $43.72 \quad(2.75)$ & $0.02 \quad(0.01)$ & $0.13 \quad(0.01)$ & $8.48 \quad(0.25)$ & $0.002 \quad(0.002)$ & 1999 & 37.18 & 61.77 & 23.56 \\
\hline Finland & 39.32 (4.47) & $0.03 \quad(0.01)$ & $0.11 \quad(0.01)$ & $8.27 \quad(0.06)$ & $0.003(0.001)$ & 1999 & 30.70 & 55.45 & 16.44 \\
\hline France & $40.35 \quad(2.36)$ & $0.02 \quad(0.01)$ & $0.11 \quad(0.01)$ & $7.85 \quad(0.13)$ & $0.006 \quad(0.003)$ & 1999 & 28.05 & 56.70 & 3.65 \\
\hline Germany & 38.74 (2.27) & $0.02 \quad(0.01)$ & $0.12 \quad(0.01)$ & $7.14 \quad(0.51)$ & $-0.002(0.004)$ & 2000 & 27.36 & 53.85 & 20.39 \\
\hline Greece & 30.94 (3.97) & $0.03 \quad(0.01)$ & $0.11 \quad(0.01)$ & $5.82(0.3)$ & 0.005 & 2003 & 13.54 & 49.76 & 0.00 \\
\hline Hungary & 19.58 (2.97) & $0.04 \quad(0.01)$ & $0.23(0.01)$ & $6.38 \quad(0.51)$ & $-0.001 \quad(0.003)$ & 2001 & 16.85 & 25.71 & 13.87 \\
\hline Iceland & $47.69 \quad(5.10)$ & $0.03(0.02)$ & $0.14(0.04)$ & $8.48 \quad(0.22)$ & $0.015(0.014)$ & 2000 & 32.82 & 58.31 & 0.45 \\
\hline Ireland & $44.08 \quad(7.02)$ & $0.05 \quad(0.02)$ & $0.09 \quad(0.01)$ & $5.59(0.16)$ & $0.021 \quad(0.004)$ & 2002 & 20.57 & 38.33 & 14.75 \\
\hline Italy & 37.74 (1.97) & $0.01 \quad(0.01)$ & - & $6.10 \quad(0.39)$ & $0.000 \quad(0.004)$ & 2000 & 19.17 & 44.45 & 0.03 \\
\hline Japan & $38.75 \quad(2.40)$ & $0.02 \quad(0.01)$ & $0.14 \quad(0.01)$ & $8.92 \quad(0.25)$ & $-0.004 \quad(0.003)$ & 1999 & 23.57 & 50.88 & 10.03 \\
\hline Netherlands & 43.43 (3.15) & $0.02 \quad(0.01)$ & $0.11 \quad(0.01)$ & $7.38 \quad(0.62)$ & $0.004 \quad(0.001)$ & 1999 & 35.83 & 54.28 & 37.34 \\
\hline New Zealand & 32.49 (2.57) & $0.02 \quad(0.01)$ & $0.13 \quad(0.01)$ & $6.04(0.12)$ & $0.012(0.004)$ & 2000 & 21.87 & 46.26 & 0.08 \\
\hline Norway & $57.36 \quad(3.49)$ & $0.02 \quad(0.01)$ & $0.11 \quad(0.01)$ & $6.96(0.2)$ & $0.008 \quad(0.002)$ & 1999 & 34.49 & 56.70 & 15.17 \\
\hline Portugal & 24.80 & $0.02 \quad(0.01)$ & - & $5.66(0.15)$ & $0.005(0.003)$ & 2000 & 15.99 & 38.74 & 1.74 \\
\hline South Korea & 25.21 (3.59) & $0.04 \quad(0.04)$ & $0.21 \quad(0.03)$ & - & $0.008 \quad(0.003)$ & 1999 & 32.04 & 43.06 & 14.60 \\
\hline Spain & 32.35 (2.70) & $0.02(0.01)$ & - & $6.42 \quad(0.43)$ & $0.013(0.013)$ & 1999 & 20.78 & 39.04 & 1.11 \\
\hline Sweden & 44.58 (4.04) & $0.02 \quad(0.01)$ & $0.12 \quad(0.01)$ & $7.63 \quad(0.13)$ & $0.005 \quad(0.002)$ & 1999 & 31.99 & 68.23 & 21.49 \\
\hline Switzerland & 46.93 (2.06) & $0.01 \quad(0.01)$ & $0.15 \quad(0.01)$ & $6.59(0.25)$ & $0.006 \quad(0.003)$ & 2000 & 33.52 & 64.64 & 34.19 \\
\hline United Kingdom & 42.33 (3.54) & $0.02(0.01)$ & $0.10 \quad(0.01)$ & $6.01 \quad(0.12)$ & $0.005(0.001)$ & 2000 & 28.54 & 52.74 & 3.56 \\
\hline United States & 54.77 (2.90) & $0.02 \quad(0.01)$ & $0.11 \quad(0.01)$ & $6.62(0.13)$ & $0.013 \quad(0.003)$ & 1998 & 25.83 & 61.79 & 23.57 \\
\hline
\end{tabular}

Notes: Means and standard deviations (in parentheses) for economic indicators over the years 1996 to 2007. Economic indicators stem from the OECD Economic Outlook. Data on years of schooling are taken from OECD Education at a Glance. Data on the emergence and diffusion of broadband are from the OECD Broadband Portal. Data on telephone access lines and on cable-TV subscribers in the year before the first emergence of broadband are taken from ITU World Telecommunication/ICT Indicators Database; broadband first emerged in Canada in 1997. Capital formation/GDP refers to the ratio of real private non-residential fixed capital formation to real private GDP. Years of education refer to the population aged 15-64. Broadband penetration rate refers to broadband subscribers per 100 inhabitants. Voice-telephony penetration rate refers to telephone access lines per 100 inhabitants. Cable-TV penetration rate refers to cable-TV subscribers per 100 inhabitants. 
Table 2: Broadband Introduction and GDP per Capita

\begin{tabular}{|c|c|c|c|}
\hline Dependent variable: Log of GDP per capita & Model 1 & Model 2 & Model 3 \\
\hline Dummy broadband introduction & $\begin{array}{c}0.023^{* *} \\
(2.59)\end{array}$ & $\begin{array}{c}0.025^{* *} \\
(2.62)\end{array}$ & $\begin{array}{l}0.019^{* *} \\
(2.09)\end{array}$ \\
\hline Log of capital formation/GDP & $\begin{array}{c}0.110^{* *} \\
(2.35)\end{array}$ & & \\
\hline Log of years of education & $\begin{array}{l}0.083 \\
(0.54)\end{array}$ & & \\
\hline Growth of working-age population & $\begin{array}{r}-0.006 \\
(0.01)\end{array}$ & & \\
\hline Country dummies & yes & yes & yes \\
\hline Year dummies & yes & yes & yes \\
\hline Constant & $\begin{array}{l}3.644^{* * *} \\
(13.03)\end{array}$ & $\begin{array}{l}3.563^{* * *} \\
(255.64)\end{array}$ & $\begin{array}{l}3.492^{* * *} \\
(304.32)\end{array}$ \\
\hline $\begin{array}{l}R^{2} \text { (within) } \\
\text { Observations } \\
\text { Countries }\end{array}$ & $\begin{array}{c}0.86 \\
240 \\
20\end{array}$ & $\begin{array}{c}0.85 \\
240 \\
20\end{array}$ & $\begin{array}{c}0.84 \\
300 \\
25\end{array}$ \\
\hline
\end{tabular}

Notes: OLS estimation for 1996-2007. Sample of OECD countries. Five countries drop from the full model due to lack of data on control variables. Robust $t$ statistics in parentheses. Significance at ${ }^{*} 10 \%,{ }^{* *} 5 \%,{ }^{* * *} 1 \%$ level. 
The coefficient of the broadband introduction dummy is positive and significant in all three models. It is slightly larger in Model 2 without controls than in Model 1, as expected. The results suggest that after a country has introduced broadband, GDP per capita is on average between 1.9 and 2.5 percent higher than before its introduction, controlling for country and year fixed effects.

Table 3 reports estimation results of equation (6) that models the effect of broadband diffusion on growth in GDP per capita in a standard cross-country growth regression framework. Again, Models 1 and 2 use the 20-country sample, where Model 1 includes changes in physical and human capital accumulation and population growth and Model 2 does not. Model 3 again uses all 25 countries. The coefficient on the broadband penetration rate is positive and significant in all three specifications. The coefficient estimate is again larger in the model without controls. The magnitude of the coefficients suggests that a ten percentagepoint increase in the broadband penetration rate is associated with an increase in the annual growth rate of GDP per capita by 0.65 to 0.91 percentage points.

However, the results of both sets of regressions cannot be interpreted as causal effects of the introduction and diffusion of broadband. As discussed above, the timing of broadband introduction and its subsequent diffusion may depend on the demand of the population for new technologies or sector-specific regulation in telecommunications, which may bias the OLS results.

\section{The Causal Effect of Broadband Infrastructure on Economic Growth}

\subsection{Instrumental Variables Derived from a Technological Diffusion Model}

The associations between broadband and economic growth reported so far may suffer from different sources of endogeneity bias. One concern is reverse causality, in that both the year of broadband introduction and its subsequent penetration may be endogenous and depend on economic development. In wealthy countries, the demand of the population for new technologies might drive the emergence and diffusion of broadband. This is in line with Comin and Hobijn (2004), who provide evidence that most of the 20 technologies they study over two centuries are adopted first in advanced economies and subsequently trickle down to countries that lag economically. 
Table 3: Broadband Diffusion and Growth of GDP per Capita

\begin{tabular}{|c|c|c|c|}
\hline Dependent variable: Growth of GDP per capita & Model 1 & Model 2 & Model 3 \\
\hline Broadband penetration rate & $\begin{array}{c}0.065^{* * *} \\
(3.08)\end{array}$ & $\begin{array}{c}0.091^{* * *} \\
(4.31)\end{array}$ & $\begin{array}{c}0.083^{* * *} \\
(3.03)\end{array}$ \\
\hline Years since broadband introduction & $\begin{array}{c}-0.003^{* * *} \\
(2.95)\end{array}$ & $\begin{array}{c}-0.004^{* * *} \\
(3.89)\end{array}$ & $\begin{array}{c}-0.003^{* *} \\
(2.59)\end{array}$ \\
\hline Growth of capital formation/GDP & $\begin{array}{c}0.069^{* * *} \\
(6.76)\end{array}$ & & \\
\hline Growth of years of education & $\begin{array}{r}-0.007 \\
(0.30)\end{array}$ & & \\
\hline$\Delta$ Growth of working-age population & $\begin{array}{l}-0.231 \\
(1.06)\end{array}$ & & \\
\hline GDP per capita in 1996 & $\begin{array}{c}-0.001^{* * *} \\
(3.90)\end{array}$ & $\begin{array}{c}-0.001^{* * *} \\
(3.97)\end{array}$ & $\begin{array}{c}-0.001^{* * *} \\
(3.68)\end{array}$ \\
\hline Constant & $\begin{array}{c}0.049^{* * *} \\
(6.98)\end{array}$ & $\begin{array}{c}0.053^{* * *} \\
(7.68)\end{array}$ & $\begin{array}{c}0.046^{* * *} \\
(8.60)\end{array}$ \\
\hline$R^{2}$ & 0.30 & 0.19 & 0.11 \\
\hline Observations & 240 & 240 & 300 \\
\hline Countries & 20 & 20 & 25 \\
\hline
\end{tabular}

Notes: OLS estimation for 1996-2007. Sample of OECD countries. Five countries drop from the full model due to lack of data on control variables. Broadband penetration rate measured as broadband subscribers per 100 inhabitants; broadband line refers download speeds of at least $256 \mathrm{kbit} / \mathrm{s}$. Robust $t$ statistics in parentheses. Significance at $10 \%,{ }^{* *} 5 \%,{ }^{* * *} 1 \%$ level. 
Another source of endogeneity may be state intervention in the telecommunication sector. State intervention will typically depend on economic development in a country, thus confounding the effect of regulation with the effect of broadband diffusion. This issue has become evident in the response to the economic crisis in 2008 and 2009, when the governments of many countries initiated economic stimulus packages to dampen the economic downturn and stimulate growth. Many of these packages emphasize investments in high-speed internet and promote the roll-out of broadband networks (OECD 2009).

We address these endogeneity concerns using an instrumental-variable (IV) approach based on the fact that most commonly used broadband standards (e.g. ADSL, VDSL) rely on the copper wire of the voice-telephony network or the coaxial cable of the cable-TV network between the main distribution frame or the street cabinet and the household. In countries where fiber is rolled out to the homes (i.e., broadband via fiber-to-the-home, FTTH), the existing ducts of the traditional networks are used to reduce deployment cost of broadband. In other words, access to one of these existing infrastructure elements built for other purposes than the provision of broadband is necessary for economically viable fixed-line broadband roll-out. These existing elements are therefore relevant instruments for fixed-line broadband deployment to determine its causal effect on economic growth. We thus assume that the maximum reach of broadband $\gamma_{i}$ (i.e., the ultimate "ceiling" of broadband penetration) is determined by the extension of the voice-telephony and cable-TV networks that existed prior to broadband infrastructure:

$$
\gamma_{i}=\gamma_{0}+\alpha_{1} t_{-} \text {net }_{i 0}+\alpha_{2} \text { cable_net }_{i 0}
$$

To represent the extent of the traditional telecommunication and cable networks, we use the number of telecommunication access lines per 100 inhabitants in the year 1996 (tel_net $i$ ) and the number of cable-TV subscribers per 100 inhabitants in 1996 (cable_net ${ }_{i 0}$ ), i.e., in the year before the first country introduced broadband. Data on telecommunication access lines and cable-TV subscribers are taken from the International Telecommunications Union (ITU) World Telecommunication/ICT Indicators Database. The last two columns of Table 1 provide descriptive statistics on both variables. The number of telecommunication access lines per 100 inhabitants in 1996 ranges from 25.7 in Hungary to 68.2 in Sweden. The number of cable-TV subscribers per 100 inhabitants in 1996 ranges from 0.03 in Italy to 37.3 in the Netherlands. 
Based on the work of Griliches (1957), a large body of research has found that the extensive margin of the diffusion of a new technology in country $i$ at time $t$ is best described through a logistic curve of the following form (Geroski 2000; Comin, Hobijn, and Rovito 2006): ${ }^{4}$

$$
B_{i t}=\frac{\gamma_{i}}{1+\exp (-\beta(t-\tau))}+\varepsilon_{i t}
$$

Again, $B_{i t}$ is the broadband penetration rate in the population. The diffusion curve can be characterized by the parameters $\gamma, \beta$, and $\tau$ that determine the maximum broadband penetration level (saturation level), the diffusion speed, and the inflexion point of the diffusion process, respectively. At the inflexion point $\tau$, the diffusion curve has its maximum growth rate $\beta / 2 . \varepsilon_{i t}$ is an error term.

Inserting equation (7) into equation (8), we obtain a non-linear first-stage equation. Based on non-linear least squares estimation, we calculate from this equation counterfactual values of broadband penetration that are determined purely by exogenous factors. We then use these predicted values of broadband penetration rates in our second-stage growth regressions. We also calculate the predicted year of broadband introduction for each country from this diffusion curve. Here, we use the year in which predicted broadband penetration reaches one percent as the predicted year of introduction of broadband. Using a non-linear first stage to generate fitted values that are subsequently used in the second-stage equation is not innocuous because it generates consistent estimates only if the non-linear first-stage model is correctly specified (Angrist and Krueger 2001). However, the vast empirical literature on technology diffusion confirming the logistic shape of the diffusion process (Geroski 2000) provides confidence in the specific non-linear model. Moreover, our first-stage diffusion model allows us to obtain time-variant predicted values of broadband penetration rates even though the instruments are time-invariant.

\subsection{Instrumental-Variable Results}

The first stage of our IV model is a logistic model of technology diffusion, estimated by nonlinear least squares. Models 1 and 2 of Table 4 present the parameter estimates of the firststage regressions using both the 20-country and the 25 -country sample. In both samples, the size of the voice-telephony network and the size of the cable-TV network have statistically

\footnotetext{
${ }^{4}$ While the logistic form tends to capture the extensive margin of diffusion (the take-up of users) - as measured in our paper - very well for a vast number of technologies, Comin, Hobijn, and Rovito (2006) show that it does not capture the intensive margin of diffusion (reflecting the intensity of use) for many technologies well.
} 
significant positive effects on the saturation level $\gamma_{i}$ of the broadband diffusion curve in a country. The $F$-tests of joint significance (26.7 and 32.2, respectively) reject the null hypothesis of both coefficients jointly being zero. The logistic shape provides a very good fit to the broadband diffusion process across countries, and the average inflexion point of the diffusion curve is estimated around the year 2004. The same holds if the control variables of the second-stage model (investment, education, and population growth) are added (Model 3). ${ }^{5}$

To illustrate the broadband diffusion curves and the fit of our first-stage models, Figure 1 plots the actual and predicted values of the broadband penetration rate for the sample of 25 OECD countries. The logistic shape of the diffusion process of broadband technology is directly visible in most countries. There is no joint pattern in the deviation of the predicted values of broadband penetration from actual values across countries. For example, in South Korea all predicted values are below the actual values, while in Germany the predicted values are consistently above the actual values. In South Korea, the government has exerted great financial effort to roll out fiber-to-the-home, resulting in high actual broadband penetration rates, which is not reflected in the predicted values. In contrast, given the high penetration rate of the cable-TV network in Germany, predicted broadband penetration rates are higher than the actual values. However, in Germany the cable-TV network was owned by the incumbent telephone network operator until 2003, which had little incentive to update the cable network for broadband purposes. After the sale of the cable network by the incumbent following pressure by the European Commission, broadband via cable networks has been evolving since 2005. Both examples show that state intervention plays an important role for broadband diffusion. However, from a political-economy perspective, these interventions might simply be the reaction to unsatisfactory developments in a country, making such interventions endogenous (Duso and Röller 2003). Our instrumental-variable approach is designed to avoid these confounding effects.

\footnotetext{
${ }^{5}$ The results reported below are based on Models 1 and 2 without additional control variables, as the two stages are estimated separately. Results are very similar when based on the first stage with additional controls.
} 
Table 4: The Diffusion Curve: First Stage of the Instrumental-Variable Model

\begin{tabular}{|c|c|c|c|}
\hline Dependent variable: Broadband penetration rate & Model 1 & Model 2 & Model 3 \\
\hline Voice-telephony penetration rate & $\begin{array}{c}0.585^{* * *} \\
(6.16)\end{array}$ & $\begin{array}{c}0.487^{* * *} \\
(4.59)\end{array}$ & $\begin{array}{c}0.653^{* * *} \\
(7.24)\end{array}$ \\
\hline Cable-TV penetration rate & $\begin{array}{c}0.279^{* *} \\
(2.11)\end{array}$ & $\begin{array}{l}0.301^{* *} \\
(2.54)\end{array}$ & $\begin{array}{l}0.334^{* *} \\
(2.47)\end{array}$ \\
\hline Diffusion speed $(\beta)$ & $\begin{array}{c}0.647^{* * *} \\
(15.60)\end{array}$ & $\begin{array}{c}0.623^{* * *} \\
(13.36)\end{array}$ & $\begin{array}{c}0.613^{* * *} \\
(9.15)\end{array}$ \\
\hline Inflexion point $(\tau)$ & $\begin{array}{c}2.004 .531^{* * *} \\
(10423.78)\end{array}$ & $\begin{array}{c}2.004 .532^{* * *} \\
(10508.86)\end{array}$ & $\begin{array}{c}2.004 .485^{* * *} \\
(7939.33)\end{array}$ \\
\hline Log of capital formation/GDP & & & $\begin{array}{c}0.035^{* *} \\
(2.24)\end{array}$ \\
\hline Log of years of education & & & $\begin{array}{l}0.034^{*} \\
(2.08)\end{array}$ \\
\hline Growth of working-age population & & & $\begin{array}{l}0.347 \\
(0.86)\end{array}$ \\
\hline Constant $\left(\gamma_{0}\right)$ & $\begin{array}{r}-0.057 \\
(1.25) \\
\end{array}$ & $\begin{array}{l}0.002 \\
(0.04) \\
\end{array}$ & $\begin{array}{c}-0.104^{* *} \\
(2.25) \\
\end{array}$ \\
\hline$R^{2}$ & 0.96 & 0.93 & 0.95 \\
\hline$F$-test $($ cable-TV pen. rate $=$ voice-tel. pen. rate $=0)$ & 26.69 & 32.18 & 31.92 \\
\hline Observations & 260 & 325 & 240 \\
\hline Countries & 20 & 25 & 20 \\
\hline
\end{tabular}

Notes: Non-linear least squares estimation for 1996-2008. Diffusion speed and inflexion point do not vary across countries. By contrast, the saturation level is country-specific and is a linear function of the voice-telephony penetration rate and the cable-TV penetration rate in the year before the first emergence of broadband. Model 3 contains additive control variables and is for 1996-2007. Sample of OECD countries. Five countries drop from the full model due to lack of data on control variables. Robust $t$ statistics in parentheses. Significance at ${ }^{*} 10 \%,{ }^{* *} 5 \%,{ }^{* * *} 1 \%$ level. 
Figure 1: Broadband Diffusion in OECD Countries: Actual and Predicted Curves

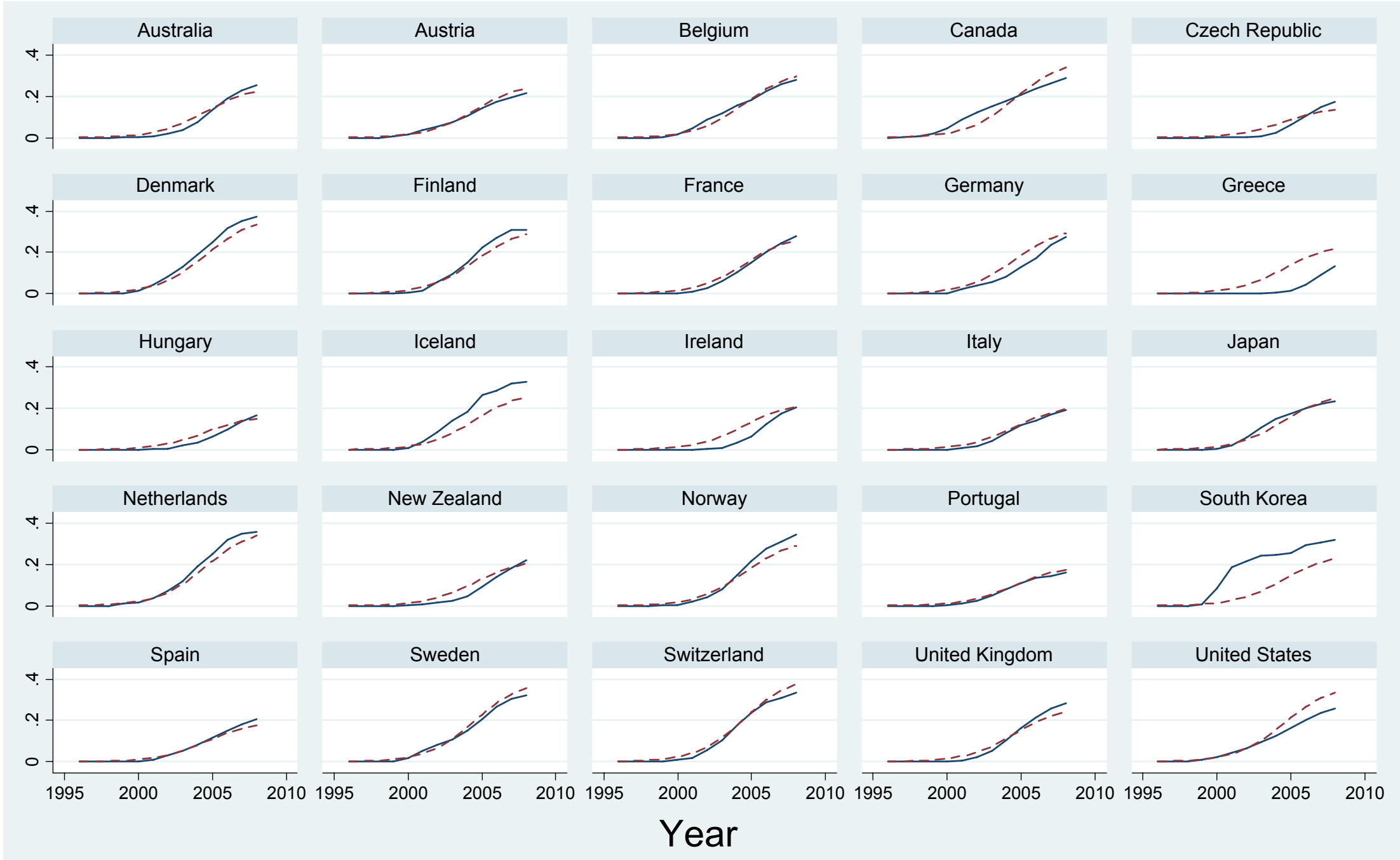

\section{Actual broadband rate --------- Predicted broadband rate}

Notes: Actual and predicted broadband penetration rates over 1996-2008 for 25 OECD countries. Predicted values are derived from non-linear least squares estimations of a diffusion curve as reported in Table 4. Diffusion speed and inflexion point do not vary across countries. By contrast, the saturation level is country-specific and is a linear function of telephone access lines per 100 inhabitants and cable-TV subscribers per 100 inhabitants in the year before the first emergence of broadband. 
Results of the second-stage model that estimates GDP per capita as a function of broadband introduction in a difference-in-differences framework (i.e. equation (4)) are reported in Models 1-3 of Table 5. In all three model specifications, broadband introduction (as predicted by the first-stage diffusion model) has a strongly significant positive effect on GDP per capita. To account for the fact that broadband penetration is itself the result of a (non-linear) first-stage estimation, standard errors are bootstrapped (500 repetitions) in this and the subsequent models. Across our three model specifications, the results imply that after the introduction of broadband, GDP per capita was 2.7 to 3.9 percent higher than before, controlling for country and year fixed effects. In all three specifications, the IV results are slightly larger than in the OLS regressions, suggesting that the OLS regressions are downward biased. However, only in Model 3 is the difference between OLS and IV estimates statistically significant.

To test the assumption of this difference-in-differences approach that countries that have not (yet) introduced broadband and countries that have introduced broadband had the same time trends before broadband introduction, Models 4-6 additionally include "placebo introduction dummies" for points in time before the introduction of broadband that is actually predicted. Specifically, the models include placebo introduction dummies for two and three years before broadband introduction, i.e., before the predicted broadband penetration rate reached 1 percent. ${ }^{6}$ The placebo introduction dummies do not enter the model significantly. What is more, the effect of broadband introduction on GDP per capita is hardly affected at all by the inclusion of the placebos. Similarly, placebo introduction dummies for two and three years after actual broadband introduction (not shown) do not enter the model significantly and do not change the result on actual broadband introduction. ${ }^{7}$

\footnotetext{
${ }^{6}$ We do not include the placebo dummy for one year before introduction because in some countries counterfactual broadband penetration rates in this year are very similar to those in the counterfactual year of introduction. The maximum of the broadband penetration rate in the year before introduction was 0.99 percent, while the minimum in the year of introduction was 1.003 percent, making the difference somewhat arbitrary. In contrast, the counterfactual broadband penetration rate for two years before introduction has a maximum value of 0.53 percent.

${ }^{7}$ Results for the post-introduction placebo dummies are available from the authors on request.
} 
Table 5: The Effect of Broadband Introduction on GDP per Capita: Second Stage of the Instrumental-Variable Model

\begin{tabular}{|c|c|c|c|c|c|c|}
\hline Dependent variable: Log of GDP per capita & Model 1 & Model 2 & Model 3 & Model 4 & Model 5 & Model 6 \\
\hline Predicted broadband introduction & $\begin{array}{c}0.027^{* * *} \\
(2.84)\end{array}$ & $\begin{array}{c}0.031^{* * *} \\
(3.18)\end{array}$ & $\begin{array}{c}0.039^{* * *} \\
(4.56)\end{array}$ & $\begin{array}{c}0.028^{* * *} \\
(2.79)\end{array}$ & $\begin{array}{c}0.031^{* * *} \\
(3.10)\end{array}$ & $\begin{array}{c}0.039^{* * *} \\
(4.60)\end{array}$ \\
\hline Log of capital formation/GDP & $\begin{array}{c}0.107^{* *} \\
(2.11)\end{array}$ & & & $\begin{array}{c}0.108^{* *} \\
(2.13)\end{array}$ & & \\
\hline Log of years of education & $\begin{array}{l}0.088 \\
(0.61)\end{array}$ & & & $\begin{array}{l}0.088 \\
(0.60)\end{array}$ & & \\
\hline Growth of working-age population & $\begin{array}{l}0.043 \\
(0.06)\end{array}$ & & & $\begin{array}{l}0.028 \\
(0.04)\end{array}$ & & \\
\hline Dummy 2 years before broadband introduction & & & & $\begin{array}{l}0.006 \\
(1.14)\end{array}$ & $\begin{array}{l}0.007 \\
(1.18)\end{array}$ & $\begin{array}{r}-0.001 \\
(0.11)\end{array}$ \\
\hline Dummy 3 years before broadband introduction & & & & $\begin{array}{l}0.010^{*} \\
(1.93)\end{array}$ & $\begin{array}{l}0.009 \\
(1.63)\end{array}$ & $\begin{array}{l}0.001 \\
(0.11)\end{array}$ \\
\hline Country dummies & yes & yes & yes & yes & yes & yes \\
\hline Year dummies & yes & yes & yes & yes & yes & yes \\
\hline Constant & $\begin{array}{c}3.627^{* * *} \\
(12.10)\end{array}$ & $\begin{array}{c}3.563^{* * *} \\
(65.67)\end{array}$ & $\begin{array}{c}3.492^{* * *} \\
(61.41)\end{array}$ & $\begin{array}{c}3.627^{* * *} \\
(12.05)\end{array}$ & $\begin{array}{l}3.561^{* * *} \\
(65.11)\end{array}$ & $\begin{array}{c}3.492^{* * *} \\
(61.22)\end{array}$ \\
\hline$R^{2}$ (within) & 0.86 & 0.85 & 0.84 & 0.86 & 0.85 & 0.84 \\
\hline Observations & 240 & 240 & 300 & 240 & 240 & 300 \\
\hline Countries & 20 & 20 & 25 & 20 & 20 & 25 \\
\hline
\end{tabular}

Notes: Second-stage estimation for 1996-2007. The year of broadband introduction is predicted from the first-stage diffusion curve reported in Table 4, referring to the year in which the predicted broadband penetration rate was larger than $1 \%$. Sample of OECD countries. Five countries drop from the full model due to lack of data on control variables. Bootstrapped $z$ statistics in parentheses. Significance at ${ }^{*} 10 \%,{ }^{* *} 5 \%,{ }^{* * *} 1 \%$ level. 
Our alternative second-stage model in equation (6) is based on a standard growth regression framework. As shown in Models 1-3 of Table 6, (first-stage predicted) broadband diffusion has a statistically significant positive effect on growth in GDP per capita. An increase in the broadband penetration rate by ten percentage points increases annual per-capita growth rates by 0.9 to 1.5 percentage points. To provide an example, 10 percentage points is approximately the difference in the broadband penetration rates between Germany and the leading OECD countries in 2003. Thus, a simple counterfactual thought experiment suggests that if in Germany broadband penetration had increased by 10 percentage points in 2003, GDP per capita would have been 3.7 to 5.9 percent higher in 2007. As in the previous model, the IV coefficients on broadband are larger than in the OLS regressions, with the difference being statistically significant in Models 2 and 3, but not in the full Model 1.

Models 4-6 add time lags in the growth-enhancing effect of broadband. This is based on the idea that the effect of dissemination and processing of information enabled by new broadband infrastructure may not show immediately but may take some time. The coefficients are hardly larger (1.2 to 1.6 percentage point growth contribution) than the baseline results in Models 13 , suggesting that nearly the whole growth-enhancing effect of broadband appears already contemporaneous to the diffusion of broadband.

In Table 7, we add a full set of country fixed effects to the growth regression. In this specification, identification comes only from variation in growth rates within countries over time. Still, we can identify significant positive effects of the broadband penetration rate on growth rates which are rather precisely identified and, in the case of the first two models, even larger than without the country fixed effects. Models 4-6 additionally include time dummies for three-year intervals (1999-2001, 2002-2004, and 2005-2007, with 1996-1998 as the reference time period) to capture different phases of global economic growth. Again, the estimated effect of broadband diffusion on growth in per-capita GDP is hardly affected. 
Table 6: The Effect of Broadband Diffusion on Growth of GDP per Capita: Second Stage of the Instrumental-Variable Model

\begin{tabular}{|c|c|c|c|c|c|c|}
\hline Dependent variable: Growth of GDP per capita & Model 1 & Model 2 & Model 3 & Model 4 & Model 5 & Model 6 \\
\hline Predicted broadband penetration rate & $\begin{array}{c}0.092^{* * *} \\
(3.57)\end{array}$ & $\begin{array}{c}0.135^{* * *} \\
(5.27)\end{array}$ & $\begin{array}{c}0.145^{* * *} \\
(4.10)\end{array}$ & & & \\
\hline Lagged predicted broadband penetration rate & & & & $\begin{array}{c}0.116^{* * *} \\
(4.05)\end{array}$ & $\begin{array}{c}0.156^{* * *} \\
(5.20)\end{array}$ & $\begin{array}{c}0.159^{* * *} \\
(4.49)\end{array}$ \\
\hline Years since predicted broadband introduction & $\begin{array}{c}-0.003^{* * *} \\
(3.92)\end{array}$ & $\begin{array}{c}-0.005^{* * *} \\
(5.40)\end{array}$ & $\begin{array}{c}-0.005^{* * *} \\
(4.03)\end{array}$ & $\begin{array}{c}-0.004^{* * *} \\
(4.66)\end{array}$ & $\begin{array}{c}-0.005^{* * *} \\
(5.53)\end{array}$ & $\begin{array}{c}-0.004^{* * *} \\
(4.24)\end{array}$ \\
\hline Growth of capital formation/GDP & $\begin{array}{c}0.069^{* * *} \\
(5.73)\end{array}$ & & & $\begin{array}{c}0.071^{* * * *} \\
(5.28)\end{array}$ & & \\
\hline Growth of years of education & $\begin{array}{l}-0.004 \\
(0.19)\end{array}$ & & & $\begin{array}{l}-0.018 \\
(1.18)\end{array}$ & & \\
\hline$\Delta$ Growth of working-age population & $\begin{array}{l}-0.18 \\
(0.77)\end{array}$ & & & $\begin{array}{l}-0.227 \\
(0.98)\end{array}$ & & \\
\hline GDP per capita in 1996 & $\begin{array}{c}-0.001^{* * *} \\
(6.06)\end{array}$ & $\begin{array}{c}-0.001^{* * *} \\
(6.57)\end{array}$ & $\begin{array}{c}-0.001^{* * *} \\
(4.38)\end{array}$ & $\begin{array}{c}-0.001^{* * *} \\
(7.01)\end{array}$ & $\begin{array}{c}-0.001^{* * *} \\
(7.24)\end{array}$ & $\begin{array}{c}-0.001^{* * *} \\
(4.18)\end{array}$ \\
\hline Constant & $\begin{array}{c}0.052^{* * *} \\
(10.29)\end{array}$ & $\begin{array}{l}0.056^{* * *} \\
(11.59)\end{array}$ & $\begin{array}{c}0.049^{* * *} \\
(8.36)\end{array}$ & $\begin{array}{c}0.057^{* * *} \\
(11.72)\end{array}$ & $\begin{array}{c}0.060^{* * *} \\
(12.33)\end{array}$ & $\begin{array}{c}0.050^{* * *} \\
(7.74)\end{array}$ \\
\hline $\begin{array}{l}R^{2} \\
\text { Observations } \\
\text { Countries }\end{array}$ & $\begin{array}{c}0.29 \\
240 \\
20\end{array}$ & $\begin{array}{c}0.19 \\
240 \\
20\end{array}$ & $\begin{array}{c}0.12 \\
300 \\
25\end{array}$ & $\begin{array}{c}0.35 \\
220 \\
20\end{array}$ & $\begin{array}{c}0.25 \\
220 \\
20\end{array}$ & $\begin{array}{c}0.14 \\
275 \\
25\end{array}$ \\
\hline
\end{tabular}

Notes: Second-stage estimation for 1996-2007. Broadband penetration rates and year of broadband introduction are predicted from the first-stage diffusion curve reported in Table 4. Sample of OECD countries. Five countries drop from the full model due to lack of data on control variables. Bootstrapped $z$ statistics in parentheses. Significance at ${ }^{*} 10 \%,{ }^{* *} 5 \%,{ }^{* * *} 1 \%$ level. 
Table 7: The Effect of Broadband Diffusion on Growth of GDP per Capita: Instrumental-Variable Results with Fixed Effects

\begin{tabular}{|c|c|c|c|c|c|c|}
\hline Dependent variable: Growth of GDP per capita & Model 1 & Model 2 & Model 3 & Model 4 & Model 5 & Model 6 \\
\hline Predicted broadband penetration rate & $\begin{array}{c}0.125^{* * *} \\
(2.97)\end{array}$ & $\begin{array}{c}0.170^{* * *} \\
(4.23)\end{array}$ & $\begin{array}{c}0.133^{* * *} \\
(2.79)\end{array}$ & $\begin{array}{c}0.135^{* * *} \\
(2.63)\end{array}$ & $\begin{array}{c}0.162^{* * *} \\
(3.62)\end{array}$ & $\begin{array}{l}0.118^{*} \\
(1.85)\end{array}$ \\
\hline Years since predicted broadband introduction & $\begin{array}{c}-0.004^{* * *} \\
(2.92)\end{array}$ & $\begin{array}{c}-0.006^{* * *} \\
(3.98)\end{array}$ & $\begin{array}{c}-0.004^{* * *} \\
(2.61)\end{array}$ & $\begin{array}{c}-0.004^{* *} \\
(2.13)\end{array}$ & $\begin{array}{c}-0.005^{* * *} \\
(2.65)\end{array}$ & $\begin{array}{c}-0.005^{* *} \\
(2.55)\end{array}$ \\
\hline Growth of capital formation/GDP & $\begin{array}{c}0.061^{* * *} \\
(4.04)\end{array}$ & & & $\begin{array}{c}0.068^{* * *} \\
(4.56)\end{array}$ & & \\
\hline Growth of years of education & $\begin{array}{l}0.003 \\
(0.14)\end{array}$ & & & $\begin{array}{l}0.002 \\
(0.11)\end{array}$ & & \\
\hline$\Delta$ Growth of working-age population & $\begin{array}{l}-0.248 \\
(1.03)\end{array}$ & & & $\begin{array}{r}-0.242 \\
(1.10)\end{array}$ & & \\
\hline Country dummies & yes & yes & yes & yes & yes & yes \\
\hline Year controls & no & no & no & yes & yes & yes \\
\hline Constant & $\begin{array}{c}0.027^{* * *} \\
(8.37)\end{array}$ & $\begin{array}{c}0.029^{* * *} \\
(9.56)\end{array}$ & $\begin{array}{c}0.028^{* * *} \\
(10.94) \\
\end{array}$ & $\begin{array}{c}0.024^{* * *} \\
(7.84)\end{array}$ & $\begin{array}{c}0.028^{* * *} \\
(8.86)\end{array}$ & $\begin{array}{c}0.026^{* * *} \\
(9.05) \\
\end{array}$ \\
\hline$R^{2}$ (within) & 0.27 & 0.15 & 0.06 & 0.30 & 0.17 & 0.10 \\
\hline Observations & 240 & 240 & 300 & 240 & 240 & 300 \\
\hline Countries & 20 & 20 & 25 & 20 & 20 & 25 \\
\hline
\end{tabular}

Notes: Second-stage estimation for 1996-2007. Broadband penetration rates and year of broadband introduction are predicted from the first-stage diffusion curve reported in Table 4. Models 4-6 include dummies for three-year time intervals (1999-2001, 2002-2004, and 2005-2007; 1996-1998 is the reference interval). Sample of OECD countries. Five countries drop from the full model due to lack of data on control variables. Bootstrapped $z$ statistics in parentheses. Significance at ${ }^{*} 10 \%$, ${ }^{* *} 5 \%,{ }^{* * *} 1 \%$ level. 
Table 8: The Effect of Broadband Diffusion on Growth of GDP per Capita: Critical Mass Specification

\begin{tabular}{|c|c|c|c|}
\hline Dependent variable: Growth of GDP per capita & Model 1 & Model 2 & Model 3 \\
\hline Predicted broadband penetration rate & $\begin{array}{r}-0.103 \\
(0.94)\end{array}$ & $\begin{array}{c}-0.061 \\
(0.55)\end{array}$ & $\begin{array}{l}0.099 \\
(0.84)\end{array}$ \\
\hline Years since predicted broadband introduction & $\begin{array}{r}-0.001 \\
(0.62)\end{array}$ & $\begin{array}{r}-0.003 \\
(1.55)\end{array}$ & $\begin{array}{c}-0.005^{* *} \\
(2.37)\end{array}$ \\
\hline Dummy for predicted broadband penetration rate $\geq 0.1$ & $\begin{array}{r}-0.013 \\
(1.23)\end{array}$ & $\begin{array}{r}-0.012 \\
(1.05)\end{array}$ & $\begin{array}{l}0.002 \\
(0.19)\end{array}$ \\
\hline Interaction (broadband pen. rate $\geq 0.1$ ) $*$ broadband pen. rate & $\begin{array}{l}0.188^{*} \\
(1.90)\end{array}$ & $\begin{array}{c}0.200^{* *} \\
(2.00)\end{array}$ & $\begin{array}{l}0.044 \\
(0.44)\end{array}$ \\
\hline Dummy for predicted broadband penetration rate $\geq 0.2$ & $\begin{array}{l}0.009 \\
(0.64)\end{array}$ & $\begin{array}{l}0.012 \\
(0.84)\end{array}$ & $\begin{array}{l}0.011 \\
(0.80)\end{array}$ \\
\hline Interaction (broadband pen. rate $\geq 0.2$ ) $*$ broadband pen. rate & $\begin{array}{r}-0.052 \\
(0.71)\end{array}$ & $\begin{array}{r}-0.075 \\
(0.97)\end{array}$ & $\begin{array}{r}-0.057 \\
(0.73)\end{array}$ \\
\hline Growth of capital formation/GDP & $\begin{array}{c}0.067^{* * *} \\
(5.59)\end{array}$ & & \\
\hline Growth of years of education & $\begin{array}{r}-0.001 \\
(0.04)\end{array}$ & & \\
\hline$\Delta$ Growth of working-age population & $\begin{array}{r}-0.213 \\
(0.90)\end{array}$ & & \\
\hline GDP per capita in 1996 & $\begin{array}{c}-0.001^{* * *} \\
(5.56)\end{array}$ & $\begin{array}{c}-0.001^{* * *} \\
(6.11)\end{array}$ & $\begin{array}{c}-0.001^{* * *} \\
(4.25)\end{array}$ \\
\hline Constant & $\begin{array}{c}0.052^{* * *} \\
(10.11)\end{array}$ & $\begin{array}{c}0.056^{* * *} \\
(11.40)\end{array}$ & $\begin{array}{c}0.049^{* * *} \\
(8.40)\end{array}$ \\
\hline $\begin{array}{l}R^{2} \\
\text { Observations } \\
\text { Countries }\end{array}$ & $\begin{array}{c}0.31 \\
240 \\
20\end{array}$ & $\begin{array}{c}0.21 \\
240 \\
20\end{array}$ & $\begin{array}{c}0.13 \\
300 \\
25\end{array}$ \\
\hline
\end{tabular}

Notes: Second-stage estimation for 1996-2007. Broadband penetration rates and year of broadband introduction are predicted from the first-stage diffusion curve reported in Table 4. Dummies for having passed $10 \%$ and $20 \%$ broadband penetration rates as well as interactions of these dummies with the broadband penetration rates are included to test for network externalities. Sample of OECD countries. Five countries drop from the full model due to lack of data on control variables. Bootstrapped $z$ statistics in parentheses. Significance at ${ }^{*} 10 \%,{ }^{* *} 5 \%,{ }^{* * *} 1 \%$ level. 
Communication infrastructure is sometimes argued to be subject to network effects. As a consequence, the effect of broadband infrastructure on economic growth may not be linear. Specifically, broadband penetration may need to reach a "critical mass" to realize its full impact on economic growth. To test for this, we include interaction terms of the predicted broadband penetration rate and step dummies for having reached at least 10 and 20 percent broadband penetration rates. Note that broadband penetration rates range between 13.5 and 37.2 percent in 2008. The results of this specification are reported in Table 8 . While multicollinearity among the different broadband measures hampers precise identification, in this specification a statistically significant positive effect of broadband penetration on economic growth emerges only when the 10 percent threshold is passed. Reaching values above 20 percent broadband penetration does not have an additional effect beyond the effect of 10 percent penetration.

\subsection{Tests for Instrument Validity and Robustness}

Existing networks for voice telephony and cable TV were completed well before the introduction of broadband and were installed for purposes other than broadband use, i.e., for voice telephony and the transmission of TV signals. Given that we measure the extent of the voice-telephony and cable networks in 1996, they are pre-determined when considering broadband diffusion. However, pre-determination does not necessarily constitute exogeneity in the econometric sense. In this section, we analyze whether the voice-telephony and cable networks might have an independent direct effect on economic growth or affect economic growth through other channels than broadband.

In principle, our instruments - the extension of the traditional telephone and cable networks might not only affect the deployment of the broadband network but also the diffusion of other growth-enhancing technologies, such as mobile telephony (Gruber and Verboven 2001; Koski and Kretschmer 2005) and computers (Caselli and Coleman 2001). To test if this is true, we consider the diffusion of mobile telephony and computers which also emerged in the 1990s. We consequently estimate diffusion curves following equation (8) for mobile telephony and computers where the ceiling $\gamma_{i}$ is again determined by the penetration of the traditional fixedline telephone network and the cable-TV network. Data on the number of mobile-telephony subscribers per 100 inhabitants and computer users per 100 inhabitants are taken from the ITU World Telecommunication/ICT Indicators Database. The results are reported in Table 9. We find no significant effects of penetration of the traditional networks on the diffusion of 
mobile telephony and computers. Voice telephony and cable TV only determine broadband diffusion and not the diffusion of other potentially growth-enhancing technologies, underlining the validity of our instruments.

Fixed-line voice telephony could also have a direct effect on growth (Röller and Waverman 2001). However, the direct effect of fixed-line voice telephony is expected to weaken with upcoming substitutes such as mobile telephony and voice-over-IP telephony, so that the direct effect of fixed-line voice telephony is likely to have subsided in our period of analysis, starting in the late $1990 \mathrm{~s} .{ }^{8}$ Moreover, our models control for the initial level of GDP per capita in 1996, the year before broadband was first introduced, which would capture any potential indirect effects of voice-telephony and cable-TV networks on GDP per capita growth through past GDP per capita.

Still, the non-linear form of our first stage allows us to test for any effects that the fixed-line voice-telephony and cable-TV networks might have on growth. In Model 1 of Table 10, we include the number of telecommunication access lines per 100 inhabitants in 1996 and the number of cable-TV subscribers per 100 inhabitants in 1996 in addition to the predicted broadband penetration as potential separate growth determinants in the second stage of our growth model. In this model, identification of the effect of broadband on growth relies on the fact that our first stage is non-linear while the second stage is a linear model, and not on excluded variables. In line with our argument that the direct impact of traditional fixed-line voice telephony on economic growth will have subsided by 1996 , both the share of telecommunication access lines and the share of cable-TV subscribers are insignificant. In contrast, broadband penetration still has a significant positive effect of similar magnitude as in our baseline IV specification.

\footnotetext{
${ }^{8}$ According to OECD (2007) figures, the time spent on public switched telephone network (PSTN) calls is declining in most OECD countries. For example, the number of PSTN minutes declined by $44 \%$ between 2003 and 2005 in Iceland and by more than $20 \%$ in Austria and Belgium. Among these minutes are increasing cases of users making calls to mobiles.
} 
Table 9: Traditional Networks and the Diffusion of Mobile Telephony and Computers

\begin{tabular}{|c|c|c|}
\hline Dependent variable: & $\begin{array}{c}\text { Model } 1 \\
\text { Mobile subscribers }\end{array}$ & $\begin{array}{c}\text { Model } 2 \\
\text { Computer users }\end{array}$ \\
\hline Voice-telephony penetration rate & $\begin{array}{l}0.257 \\
(0.79)\end{array}$ & $\begin{array}{l}3.049^{*} \\
(2.03)\end{array}$ \\
\hline Cable-TV penetration rate & $\begin{array}{l}-0.186 \\
(0.74)\end{array}$ & $\begin{array}{l}0.700 \\
(0.94)\end{array}$ \\
\hline Diffusion speed $(\beta)$ & $\begin{array}{l}0.548^{* * *} \\
(12.38)\end{array}$ & $\begin{array}{l}0.149^{* * *} \\
(5.53)\end{array}$ \\
\hline Inflexion point $(\tau)$ & $\begin{array}{c}1.999 .347^{* * *} \\
(11636.54)\end{array}$ & $\begin{array}{c}2.005 .767^{* * *} \\
(367.34)\end{array}$ \\
\hline Constant $\left(\gamma_{0}\right)$ & $\begin{array}{c}0.827^{* * *} \\
(5.11)\end{array}$ & $\begin{array}{r}-0.497 \\
(1.25) \\
\end{array}$ \\
\hline$R^{2}$ & 0.96 & 0.95 \\
\hline$F$-test $($ cable-TV pen. rate $=$ voice-tel. pen. rate $=0$ ) & 0.67 & 2.06 \\
\hline Observations & 200 & 183 \\
\hline Countries & 20 & 20 \\
\hline
\end{tabular}

Notes: Non-linear least squares estimation for 1996-2005. Diffusion speed and inflexion point do not vary across countries. By contrast, the saturation level is country-specific and is a linear function of telephone access lines per 100 inhabitants and cable-TV subscribers per 100 inhabitants in the year before the first emergence of broadband. Sample of OECD countries. Five countries drop from the full model due to lack of data on control variables. Robust $t$ statistics in parentheses. Significance at ${ }^{*} 10 \%,{ }^{* *} 5 \%,{ }^{* * *} 1 \%$ level. 
Table 10: Additional Robustness Specifications

\begin{tabular}{|c|c|c|c|c|}
\hline Dependent variable: Growth of GDP per capita & Model 1 & Model $2^{\mathrm{a}}$ & Model 3 & Model 4 \\
\hline Predicted broadband penetration rate & $\begin{array}{c}0.090^{* * *} \\
(3.26)\end{array}$ & $\begin{array}{c}0.104^{* * *} \\
(3.57)\end{array}$ & $\begin{array}{c}0.084^{* * *} \\
(3.29)\end{array}$ & $\begin{array}{c}0.097^{* * *} \\
(3.64)\end{array}$ \\
\hline Years since predicted broadband introduction & $\begin{array}{c}-0.003^{* * *} \\
(3.75)\end{array}$ & $\begin{array}{c}-0.004^{* * *} \\
(3.78)\end{array}$ & $\begin{array}{c}-0.003^{* * *} \\
(3.99)\end{array}$ & $\begin{array}{c}-0.004^{* * *} \\
(3.98)\end{array}$ \\
\hline Voice-telephony penetration rate & $\begin{array}{l}-0.009 \\
(0.95)\end{array}$ & & & \\
\hline Cable-TV penetration rate & $\begin{array}{l}-0.003 \\
(0.37)\end{array}$ & & & \\
\hline Trade openness & & & $\begin{array}{c}0.007^{* * *} \\
(2.83)\end{array}$ & \\
\hline Log of years of education & & & & $\begin{array}{l}-0.009 \\
(1.22)\end{array}$ \\
\hline Growth of capital formation/GDP & $\begin{array}{c}0.069^{* * *} \\
(5.47)\end{array}$ & $\begin{array}{c}0.070^{* * *} \\
(5.07)\end{array}$ & $\begin{array}{c}0.073^{* * *} \\
(6.14)\end{array}$ & $\begin{array}{c}0.069^{* * *} \\
(5.54)\end{array}$ \\
\hline Growth of years of education & $\begin{array}{l}-0.002 \\
(0.09)\end{array}$ & $\begin{array}{l}-0.001 \\
(0.03)\end{array}$ & $\begin{array}{l}-0.008 \\
(0.35)\end{array}$ & $\begin{array}{c}0.0004 \\
(0.02)\end{array}$ \\
\hline$\Delta$ Growth of working-age population & $\begin{array}{l}-0.174 \\
(0.75)\end{array}$ & $\begin{array}{l}-0.196 \\
(0.78)\end{array}$ & $\begin{array}{l}-0.195 \\
(0.87)\end{array}$ & $\begin{array}{l}-0.179 \\
(0.76)\end{array}$ \\
\hline GDP per capita in 1996 & $\begin{array}{c}-0.001^{* * *} \\
(4.94)\end{array}$ & $\begin{array}{c}-0.001^{* * *} \\
(5.44)\end{array}$ & $\begin{array}{c}-0.001^{* * *} \\
(4.59)\end{array}$ & $\begin{array}{c}-0.001^{* * *} \\
(5.84)\end{array}$ \\
\hline Constant & $\begin{array}{c}0.054^{* * *} \\
(8.80)\end{array}$ & $\begin{array}{c}0.053^{* * *} \\
(9.58)\end{array}$ & $\begin{array}{c}0.042^{* * *} \\
(6.96)\end{array}$ & $\begin{array}{c}0.067^{* * *} \\
(4.56)\end{array}$ \\
\hline$R^{2}$ & 0.23 & 0.29 & 0.32 & 0.30 \\
\hline Observations & 240 & 216 & 240 & 240 \\
\hline Countries & 20 & 18 & 20 & 20 \\
\hline
\end{tabular}

Notes: Second-stage estimation for 1996-2007. Broadband penetration rates and year of broadband introduction are predicted from the first-stage diffusion curve reported in Table 4. Sample of OECD countries. Five countries drop from the full model due to lack of data on control variables. Bootstrapped $z$ statistics in parentheses. Significance at ${ }^{*}$ $10 \%,{ }^{* *} 5 \%,{ }^{* * *} 1 \%$ level. ${ }^{a}$ Model 2 excludes Canada and the United States. 
As an additional aspect, one might argue that countries that are prone to competition, market liberalization, deregulation, and international trade may also have had a highly developed voice-telephone and cable-TV network. To test for this, we exclude Canada and the United States from our sample as in all other countries, the preexisting networks were deployed by state monopolies. Thus, remaining countries seem to share similar attitudes towards market liberalization and regulation at least in the telecommunication sector. ${ }^{9}$ We further control for trade openness as measured by the sum of imports and exports over GDP, since broadband deployment might also reflect the level of openness and connectedness of a country. Data on imports and exports are from the OECD Economic Outlook. Both excluding Canada and the United States (Model 2 in Table 10) and adding trade openness (Model 3) does not change our basic result of broadband having a positive and economically meaningful effect on economic growth.

Cross-country analyses on technology diffusion demonstrate that the adoption of new technologies is associated with high levels of human capital (Caselli and Coleman 2001; Caroli and Van Reenen 2002). Models of endogenous growth (Lucas 1988; Romer 1990; Aghion and Howitt 1998) further state that the effect of human capital is not limited to increased labor productivity. Human capital also increases the innovative capacity of an economy, which in turn results in new processes and products, consequently promoting growth. Therefore, one could argue that the diffusion of broadband may proxy for the level of human capital. To test for this, we include the average number of years of schooling of the working-age population in levels in addition to its growth rate in our growth regression. ${ }^{10}$ The results are presented in Model 4 of Table 10. Again, including the level of years of schooling does not diminish the impact of broadband diffusion on economic growth. ${ }^{11}$

\footnotetext{
${ }^{9}$ Alternatively, one might add a regulatory index that reflects the attitudes towards regulation in the different countries. However, consistent time series on regulatory attitudes are not available for our complete observation period. Moreover, the development of attitudes towards regulation is not exogenous but may depend on the evolution of the telecommunication sector and the economy.

${ }^{10}$ For a discussion of empirical evidence on the effects of levels of and growth in years of schooling, see Hanushek and Woessmann (2008).

${ }^{11}$ We experimented with firm-level micro data from the Community Innovation Survey (CIS) of the European Union to gauge at possible channels through which broadband may affect growth. Unfortunately, for our purposes this database provides only two waves (CIS3 in 1998-2000 and CIS4 in 2002-2004) for nine countries (covering some 70,000 firms). Although these data limitations prohibit far-reaching interpretations, controlling for country and time fixed effects and clustering standard errors at the country x survey level, we find a positive effect of the national broadband penetration rate on radical product innovations that are new to the market and on process innovations. Detailed results are available from the authors upon request.
} 


\section{Conclusion}

In this paper, we analyzed the effects of broadband infrastructure on economic growth. Based on annual data for a panel of OECD countries and using an instrumental-variable approach, we find that the introduction and diffusion of broadband had an important impact on growth in GDP per capita. After a country has introduced broadband, GDP per capita is 2.7 to 3.9 percent higher on average than before its introduction, controlling for country and year fixed effects. In terms of subsequent diffusion, an increase in the broadband penetration rate by 10 percentage points raises annual growth in per-capita GDP by 0.9 to 1.5 percentage points.

Our results are robust to numerous tests and the inclusion of additional control variables. Our instrument for the supply of broadband, the penetration of underlying network infrastructure technologies, is successful in removing potential sources of reverse causality between growth and broadband diffusion and is shown to determine the deployment of broadband, but not of other technologies emerging around the same time. This provides confidence that our approach indeed isolates the causal effect of broadband infrastructure.

We close by discussing two limitations of our study. First, our measure of broadband is a rough one insofar as it considers any bandwidth over $256 \mathrm{kbit} / \mathrm{s}$ to be broadband. That is, the available data does not allow us to consider differences in the average or maximum bandwidths across countries, so that we concentrate on analyzing the extensive margin of broadband diffusion, i.e., the number of broadband users. Clearly, extensive diffusion may not tell the full story, as a new technology may be used more or less intensively by its users. ${ }^{12}$ However, as we are interested in the wide range of opportunities arising from increasing broadband deployment, extensive diffusion constitutes an informative measure. Second, given that broadband did not emerge until the mid-1990s and that technologies get replaced by new technologies like mobile broadband, our results represent medium-term effects for the period in which fixed broadband represents the main driver to enable firms to improve through new products, processes, and business models. Long-run projections of the effect of broadband on growth cannot be made without a longer sample period and a better understanding of the role that broadband may play in triggering further infrastructure innovations in the future. However, our results show an economically significant and robust effect of broadband diffusion on economic growth even in the time span of just over a decade. This evidence can

\footnotetext{
${ }^{12}$ Grajek and Kretschmer (2009) document and analyze the considerable heterogeneity across users and countries for the case of mobile telephony.
} 
serve as a lower bound for the potential long-term effects of broadband infrastructure, which can be adequately assessed only once longer time series become available. 


\section{References}

Aghion, P., and P. Howitt (1998). Endogenous Growth Theory. Cambridge, MA: MIT Press.

Angrist, J.D., and A.B. Krueger (2001). Instrumental Variable and the Search for Identification: From Supply and Demand to Natural Experiments. Journal of Economic Perspectives 15 (4), 69-85.

Aschauer, D.A. (1989). Is Public Expenditure Productive? Journal of Monetary Economics 23 (2), 177-200.

Audretsch, D.B., and M.P. Feldman (1996). R\&D Spillovers and the Geography of Innovation and Production. American Economic Review 86 (3), 630-640.

Autor, D., F. Levy, and R. Murnane (2003). The Skill Content of Recent Technological Change: An Empirical Exploration. Quarterly Journal of Economics 118 (4), 1279-1333.

Barro, R. (1991). Economic Growth in a Cross Section of Countries. Quarterly Journal of Economics 106 (2), 407-443.

Benhabib, J., and M.M. Spiegel (2005). Human Capital and Technology Diffusion. In: Handbook of Economic Growth, Volume 1A, P. Aghion and S.N. Durlauf (eds.), 935-966. Amsterdam: Elsevier.

Bloom, N., T. Kretschmer, and J. Van Reenen (2009). Determinants and Consequences of Family-Friendly Workplace Practices: An International Study. Strategic Management Journal: forthcoming.

Bloom, N., and J. Van Reenen (2007). Measuring and Explaining Management Practices Across Firms and Countries. Quarterly Journal of Economics 122 (4), 1351-1408.

Bresnahan, T., E. Brynjolfsson, and L. Hitt (2002). Information Technology, Workplace Organization, and the Demand for Skilled Labor: Firm Level Evidence. Quarterly Journal of Economics 117 (1), 339-376.

Caroli, E., and J. Van Reenen (2002). Skill Biased Organizational Change? Evidence from British and French Establishments. Quarterly Journal of Economics 116 (4), 1449-1492.

Caselli, F., and W.J. Coleman (2001). Cross-Country Technology Diffusion: The Case of Computers. American Economic Review 91 (2), 328-335.

Comin, D., and B. Hobijn (2004). Cross-Country Technology Adoption: Making the Theories Face the Facts. Journal of Monetary Economics 51 (1), 39-83. 
Comin, D., B. Hobijn, and E. Rovito (2006). Five Facts You Need to Know About Technology Diffusion. NBER Working Paper 11928. Cambridge, MA: National Bureau for Economic Research.

Comin, D., B. Hobijn, and E. Rovito (2008). Technology Usage Lags. Journal of Economic Growth 13 (4), 237-256.

Crafts, N. (2004). Steam as a General Purpose Technology: A Growth Accounting Perspective. Economic Journal 114 (495), 338-351.

Crandall, R., W. Lehr, and R. Litan (2007). The Effects of Broadband Deployment on Output and Employment: A Cross-sectional Analysis of U.S. Data. Issues in Economic Policy, Number 6. Washington, DC: The Brookings Institution.

Duso, T., and L.-H. Röller (2003). Endogenous Deregulation: Evidence from OECD Countries. Economics Letters 81 (1), 67-71.

Fernald, J.G. (1999). Roads to Prosperity? Assessing the Link between Public Capital and Productivity. American Economic Review 89 (3), 619-638.

Geroski, P. (2000). Models of Technology Diffusion. Research Policy 29 (4-5), 603-625.

Gillett, S.E., W.H. Lehr, C.A. Osorio, and M.A. Sirbu (2006). Measuring the Economic Impact of Broadband Deployment. Final Report, National Technical Assistance, Training, Research, and Evaluation Project \#99-07-13829.

Grajek, M., and T. Kretschmer (2009). Usage and Diffusion of Cellular Telephony, 19982004. International Journal of Industrial Organization 27 (2), 238-249.

Gramlich, E. (1994). Infrastructure Investment: A Review Essay. Journal of Economic Literature 32 (3), 1176-1196.

Griliches, Z. (1957). Hybrid Corn: An Exploration in the Economics of Technological Change. Econometrica 25 (4), 501-522.

Gruber, H., and F. Verboven (2001). The Diffusion of Mobile Telecommunications Services in the European Union. European Economic Review 45 (3), 577-588.

Hanushek, E.A., and L. Woessmann (2008). The Role of Cognitive Skills in Economic Development. Journal of Economic Literature 46 (3), 607-668.

Harris, R. (1998). The Internet as a GPT: Factor Market Implications. In: General Purpose Technologies and Economic Growth, E. Helpman (ed.), 145-166. Cambridge, MA: MIT Press. 
Hayek, F.A. von (1945). The Use of Knowledge in Society. American Economic Review 35 (4), 519-530.

Helpman, E., and M. Trajtenberg (1998). Diffusion of General Purpose Technologies. In: General Purpose Technologies and Economic Growth, E. Helpman (ed.), 85-120. Cambridge, MA: MIT Press.

Jorgensen, D.W., M.S. Ho, and K.J. Stiroh (2008). A Retrospective Look at the U.S. Productivity Growth Resurgence. Journal of Economic Perspectives 22 (1), 3-24.

Koski, H., and T. Kretschmer (2005). Entry, Standards and Competition: Firm Strategies and the Diffusion of Mobile Telephony. Review of Industrial Organization, 26 (1), 89-113.

Lucas, R.E. (1988). On the Mechanics of Economic Development. Journal of Monetary Economics 22 (1), 3-42.

Mankiw, N.G., D. Romer, and D.N. Weil (1992). A Contribution to the Empirics of Economic Growth. Quarterly Journal of Economics 107 (2), 407-437.

Munnell, A.H. (1992). Infrastructure Investment and Economic Growth. Journal of Economic Perspectives 6 (4), 189-198.

Nelson, R.R., and E. Phelps (1966). Investment in Humans, Technology Diffusion, and Economic Growth. American Economic Review 56 (2), 69-75.

OECD (2000). Economic Outlook 2000. Paris: Organisation for Economic Co-operation and Development.

OECD (2007). Communication Outlook 2007. Paris: Organisation for Economic Co-operation and Development.

OECD (2009). Policy Responses to the Economic Crisis: Investing in Innovation for LongTerm Growth. Paris: Organisation for Economic Co-operation and Development.

Röller, L.-H., and L. Waverman (2001). Telecommunications Infrastructure and Economic Development: A Simultaneous Approach. American Economic Review 91 (4), 909-923.

Romer, P.M. (1990). Endogenous Technological Change. Journal of Political Economy 98 (5), S71-S102.

Stiroh, K. (2002). Information Technology and the U.S. Productivity Revival: What Do the Industry Data Say? American Economic Review 92 (5), 1559-1576. 


\section{CESifo Working Paper Series}

for full list see www.cesifo-group.org/wp

(address: Poschingerstr. 5, 81679 Munich, Germany, office@cesifo.de)

2797 Margit Osterloh and Bruno S. Frey, Research Governance in Academia: Are there Alternatives to Academic Rankings?, September 2009

2798 Thiess Buettner and Clemens Fuest, The Role of the Corporate Income Tax as an Automatic Stabilizer, September 2009

2799 Annette Alstadsæter, Measuring the Consumption Value of Higher Education, September 2009

2800 Peter Friedrich, Chang Woon Nam and Janno Reiljan, Local Fiscal Equalization in Estonia: Is a Reform Necessary?, September 2009

2801 Evžen Kočenda and Jan Hanousek, State Ownership and Control in the Czech Republic, September 2009

2802 Michael Stimmelmayr, Wage Inequality in Germany: Disentangling Demand and Supply Effects, September 2009

2803 Biswa N. Bhattacharyay, Towards a Macroprudential Surveillance and Remedial Policy Formulation System for Monitoring Financial Crisis, September 2009

2804 Margarita Katsimi, Sarantis Kalyvitis and Thomas Moutos, "Unwarranted" Wage Changes and the Return on Capital, September 2009

2805 Christian Lessmann and Gunther Markwardt, Aid, Growth and Devolution, September 2009

2806 Bas Jacobs and Dirk Schindler, On the Desirability of Taxing Capital Income to Reduce Moral Hazard in Social Insurance, September 2009

2807 Hans Gersbach and Noemi Hummel, Climate Policy and Development, September 2009

2808 David E. Wildasin, Fiscal Competition for Imperfectly-Mobile Labor and Capital: A Comparative Dynamic Analysis, September 2009

2809 Johan Eyckmans and Cathrine Hagem, The European Union's Potential for Strategic Emissions Trading through Minimal Permit Sale Contracts, September 2009

2810 Ruediger Bachmann and Christian Bayer, The Cross-section of Firms over the Business Cycle: New Facts and a DSGE Exploration, October 2009

2811 Slobodan Djajić and Michael S. Michael, Temporary Migration Policies and Welfare of the Host and Source Countries: A Game-Theoretic Approach, October 2009 
2812 Devis Geron, Social Security Incidence under Uncertainty Assessing Italian Reforms, October 2009

2813 Max-Stephan Schulze and Nikolaus Wolf, Economic Nationalism and Economic Integration: The Austro-Hungarian Empire in the Late Nineteenth Century, October 2009

2814 Emilia Simeonova, Out of Sight, Out of Mind? The Impact of Natural Disasters on Pregnancy Outcomes, October 2009

2815 Dan Kovenock and Brian Roberson, Non-Partisan 'Get-Out-the-Vote' Efforts and Policy Outcomes, October 2009

2816 Sascha O. Becker, Erik Hornung and Ludger Woessmann, Catch Me If You Can: Education and Catch-up in the Industrial Revolution, October 2009

2817 Horst Raff and Nicolas Schmitt, Imports, Pass-Through, and the Structure of Retail Markets, October 2009

2818 Paul De Grauwe and Daniel Gros, A New Two-Pillar Strategy for the ECB, October 2009

2819 Guglielmo Maria Caporale, Thouraya Hadj Amor and Christophe Rault, International Financial Integration and Real Exchange Rate Long-Run Dynamics in Emerging Countries: Some Panel Evidence, October 2009

2820 Saša Žiković and Randall K. Filer, Hybrid Historical Simulation VaR and ES: Performance in Developed and Emerging Markets, October 2009

2821 Panu Poutvaara and Andreas Wagener, The Political Economy of Conscription, October 2009

2822 Steinar Holden and Åsa Rosén, Discrimination and Employment Protection, October 2009

2823 David G. Mayes, Banking Crisis Resolution Policy - Lessons from Recent Experience Which elements are needed for robust and efficient crisis resolution?, October 2009

2824 Christoph A. Schaltegger, Frank Somogyi and Jan-Egbert Sturm, Tax Competition and Income Sorting: Evidence from the Zurich Metropolitan Area, October 2009

2825 Natasa Bilkic, Thomas Gries and Margarethe Pilichowski, Stay in School or Start Working? - The Human Capital Investment Decision under Uncertainty and Irreversibility, October 2009

2826 Hartmut Egger and Udo Kreickemeier, Worker-Specific Effects of Globalisation, October 2009

2827 Alexander Fink and Thomas Stratmann, Institutionalized Bailouts and Fiscal Policy: The Consequences of Soft Budget Constraints, October 2009 
2828 Wolfgang Ochel and Anja Rohwer, Reduction of Employment Protection in Europe: A Comparative Fuzzy-Set Analysis, October 2009

2829 Rainald Borck and Martin Wimbersky, Political Economics of Higher Education Finance, October 2009

2830 Torfinn Harding and Frederick van der Ploeg, Is Norway's Bird-in-Hand Stabilization Fund Prudent Enough? Fiscal Reactions to Hydrocarbon Windfalls and Graying Populations, October 2009

2831 Klaus Wälde, Production Technologies in Stochastic Continuous Time Models, October 2009

2832 Biswa Bhattacharyay, Dennis Dlugosch, Benedikt Kolb, Kajal Lahiri, Irshat Mukhametov and Gernot Nerb, Early Warning System for Economic and Financial Risks in Kazakhstan, October 2009

2833 Jean-Claude Trichet, The ECB's Enhanced Credit Support, October 2009

2834 Hans Gersbach, Campaigns, Political Mobility, and Communication, October 2009

2835 Ansgar Belke, Gunther Schnabl and Holger Zemanek, Real Convergence, Capital Flows, and Competitiveness in Central and Eastern Europe, October 2009

2836 Bruno S. Frey, Simon Luechinger and Alois Stutzer, The Life Satisfaction Approach to Environmental Valuation, October 2009

2837 Christoph Böhringer and Knut Einar Rosendahl, Green Serves the Dirtiest: On the Interaction between Black and Green Quotas, October 2009

2838 Katarina Keller, Panu Poutvaara and Andreas Wagener, Does Military Draft Discourage Enrollment in Higher Education? Evidence from OECD Countries, October 2009

2839 Giovanni Cespa and Xavier Vives, Dynamic Trading and Asset Prices: Keynes vs. Hayek, October 2009

2840 Jan Boone and Jan C. van Ours, Why is there a Spike in the Job Finding Rate at Benefit Exhaustion?, October 2009

2841 Andreas Knabe, Steffen Rätzel and Stephan L. Thomsen, Right-Wing Extremism and the Well-Being of Immigrants, October 2009

2842 Andrea Weber and Christine Zulehner, Competition and Gender Prejudice: Are Discriminatory Employers Doomed to Fail?, November 2009

2843 Hadi Salehi Esfahani, Kamiar Mohaddes and M. Hashem Pesaran, Oil Exports and the Iranian Economy, November 2009

2844 Ruediger Bachmann and Christian Bayer, Firm-Specific Productivity Risk over the Business Cycle: Facts and Aggregate Implications, November 2009 
2845 Guglielmo Maria Caporale, Burcu Erdogan and Vladimir Kuzin, Testing for Convergence in Stock Markets: A Non-Linear Factor Approach, November 2009

2846 Michèle Belot and Jan Fidrmuc, Anthropometry of Love - Height and Gender Asymmetries in Interethnic Marriages, November 2009

2847 Volker Nitsch and Nikolaus Wolf, Tear Down this Wall: On the Persistence of Borders in Trade, November 2009

2848 Jan K. Brueckner and Stef Proost, Carve-Outs Under Airline Antitrust Immunity, November 2009

2849 Margarita Katsimi and Vassilis Sarantides, The Impact of Fiscal Policy on Profits, November 2009

2850 Scott Alan Carson, The Relationship between Stature and Insolation: Evidence from Soldiers and Prisoners, November 2009

2851 Horst Raff and Joachim Wagner, Intra-Industry Adjustment to Import Competition: Theory and Application to the German Clothing Industry, November 2009

2852 Erkki Koskela, Impacts of Labor Taxation with Perfectly and Imperfectly Competitive Labor Markets under Flexible Outsourcing, November 2009

2853 Cletus C. Coughlin and Dennis Novy, Is the International Border Effect Larger than the Domestic Border Effect? Evidence from U.S. Trade, November 2009

2854 Johannes Becker and Clemens Fuest, Source versus Residence Based Taxation with International Mergers and Acquisitions, November 2009

2855 Andreas Hoffmann and Gunther Schnabl, A Vicious Cycle of Manias, Crashes and Asymmetric Policy Responses - An Overinvestment View, November 2009

2856 Xavier Vives, Strategic Supply Function Competition with Private Information, November 2009

2857 M. Hashem Pesaran and Paolo Zaffaroni, Optimality and Diversifiability of Mean Variance and Arbitrage Pricing Portfolios, November 2009

2858 Davide Sala, Philipp J.H. Schröder and Erdal Yalcin, Market Access through Bound Tariffs, November 2009

2859 Ben J. Heijdra and Pim Heijnen, Environmental Policy and the Macroeconomy under Shallow-Lake Dynamics, November 2009

2860 Enrico Spolaore, National Borders, Conflict and Peace, November 2009

2861 Nina Czernich, Oliver Falck, Tobias Kretschmer and Ludger Woessmann, Broadband Infrastructure and Economic Growth, December 2009 